\title{
Pengembangan Lembar Kerja Siswa (LKS) Berbasis Problem Solving untuk Memfasilitasi Kemampuan Pemecahan Masalah Matematis Siswa Madrasah Tsanawiyah
}

\author{
Hadinurdina, Annisah Kurniati \\ Program studi pendidikan matematika, Universitas Islam Negeri Sultan Syarif Kasim Riau \\ e-mail: annisa.kurniati@uin-suska.ac.id
}

\begin{abstract}
ABSTRAK. Kemampuan pemecahan masalah merupakan salah satu komponen penting yang harus dimiliki siswa dalam menyelesaikan suatu permasalahan baik dalam pembelajaran maupun dalam kehidupan sehari hari. Penelitian ini bertujuan untuk menghasilkan bahan ajar berupa lembar kerja siswa yang valid dan praktis, serta dapat memfasilitasi kemampuan pemecahan masalah matematis siswa. Jenis penelitian ini merupakan penelitian pengembangan dengan menggunakan model pengembangan ADDIE. Penelitian ini dilakukan di MTsN Terantang Kec. Tambang Kab. Kampar. Subjek penelitian adalah dosen dan guru sebagai validator serta siswa kelas VII MTsN Terantang. Objek penelitian adalah lembar kerja siswa berbasis Problem Solving. Instrumen yang digunakan berupa lembar uji validitas, angket uji praktikalitas dan posttest. Lembar uji validitas bertujuan untuk mengetahui tingkat kevalidan, angket uji praktikalitas untuk mengetahui tingkat kepraktisan dan posttest untuk mengetahui kemampuan pemecahan masalah matematis siswa. Data yang diperoleh dianalisis dengan teknik analisis deskriptif. Lembar kerja siswa yang dihasilkan telah teruji dengan tingkat kevalidan $83,82 \%$ (sangat valid), tingkat kepraktisan 85,22\% (sangat praktis) dan tingkat kemampuan pemecahan masalah matematis siswa $80,20 \%$ (tinggi). Dari hasil tersebut menunjukkan bahwa lembar kerja siswa yang dikembangkan layak dan praktis, serta dapat memfasilitasi kemampuan pemecahan masalah matematis siswa.
\end{abstract}

Kata kunci: Lembar Kerja Siswa, Pendekatan Problem Solving, Kemampuan Pemecahan Masalah Matematis dan Model ADDIE.

\section{PENDAHULUAN}

Kemampuan pemecahan masalah merupakan kemampuan yang harus dimiliki oleh siswa dalam pembelajaran matematika. Pemecahan masalah merupakan proses menerapkan pengetahuan (knowledge) yang telah diperoleh siswa sebelumnya kedalam situasi yang baru (Ahmad, 2013: 195). Pemecahan masalah juga merupakan aktivitas yang sangat penting dalam pembelajaran matematika, karena tujuan belajar yang ingin dicapai dalam pemecahan masalah berkaitan dengan kehidupan sehari-hari. Melalui pemecahan masalah konsep yang telah dimiliki siswa dapat diaplikasikan dalam bentuk persoalan maupun dalam kehidupan nyata.

Kemampuan pemecahan masalah merupakan suatu kemampuan yang menjadi dasar untuk kemampuan lainnya, seperti kemampuan komunikasi, penalaran, berfikir kritis dan kreatif. Menurut Fadjar Sadiq (2004: 16) kemampuan pemecahan masalah akan menjadi hal yang akan sangat menentukan keberhasilan pendidikan matematika, sehingga pengintegrasian pemecahan masalah (problem solving) selama proses pembelajaran berlangsung hendaknya menjadi suatu keharusan. Oleh karena itu diperlukan upaya dari guru agar kemampuan pemecahan masalah siswa menjadi lebih baik. Salah satu upaya yang dapat dilakukan untuk mengembangkan kemampuan pemecahan masalah matematis siswa ialah dengan memfasilitasi penggunaan bahan ajar dalam pembelajaran. Sebagaimana pendapat Djamarah (2010: 210) bahwa dalam pembelajaran kehadiran media mempunyai arti yang cukup penting, karena dalam kegiatan 
tersebut ketidakjelasan bahan yang disampaikan dapat dibantu dengan menghadirkan media sebagai perantara.

Bahan ajar yang dapat dikembangkan untuk mengarahkan pola pikir siswa dan membangun kemandirian siswa salah satunya adalah Lembar Kerja Siswa (LKS). Peneliti akan membuat LKS menjadi lebih menarik, sehingga membuat siswa termotivasi dan memberikan banyak latihan soal pemecahan masalah sehingga LKS mampu memfasilitasi kemampuan pemecahan masalah matematis siswa. LKS berisi tugas dan langkah-langkah yang menuntun siswa mengelola pola pikir secara terarah dan diharapkan siswa dapat belajar secara mandiri, memahami dan menjalankan suatu secara tertulis (Abdul Majid, 2008: 177). Dengan sistem pembelajaran LKS, siswa mendapat kesempatan lebih banyak untuk belajar sendiri namun tetap dalam bimbingan guru, membaca uraian, dan memahami petunjuk didalam lembaran kegiatan, menjawab pertanyaan-pertanyaan serta melaksanakan tugas-tugas yang harus diselesaikan. Karena itu setiap siswa dalam batas-batas tertentu dapat maju sesuai dengan irama kecepatan dan kemampuan masing-masing (Mulyasa, 2009: 234).

Selain memfasilitasi siswa dengan bahan ajar, dibutuhkan juga suatu strategi pembelajaran yang dapat mendukung mengembangkan kemampuan pemecahan masalah matematis siswa yaitu pendekatan problem solving. Pendekatan Problem Solving merupakan pencarian solusi dari suatu permasalahan dengan menggunakan identifikasi, mengeksplorasi, mencari langkah-langkah pemecahan masalah dan akhir menemukan solusi tersebut serta megevaluasi solusi dari permasalahan tersebut. Dalam pendekatan Problem Solving, pembelajaran matematika diawali dengan menghadirkan siswa pada masalah (Jarnawi, 2011: 429). Pendekatan Problem Solving membimbing siswa untuk menyelesaikan permasalahan matematika dengan membentuk langkahlangkah yang jelas untuk mendapatkan hasilnya, sehingga siswa dapat menyusun pengetahuannya sendiri, lebih aktif dalam kegiatan pembelajaran, menumbuhkembangkan keterampilan yang tinggi dan meningkatkan kepercayaan dirinya.

Berdasarkan hasil wawancara dengan salah seorang guru matematika di MTsN Terantang, Kecamatan Tambang, Kabupaten Kampar, menyatakan bahwa sekolah telah menyediakan buku cetak kontekstual dan LKS. Namun buku cetak dan LKS yang digunakan ini berisi materi dan soal-soal rutin yang sudah sering ditemui oleh siswa artinya dalam buku dan LKS tersebut tidak memuat aktivitas belajar yang melibatkan siswa secara langsung dalam menemukan dan memperdalam kemampuan pemecahan masalah matematis. Selain itu guru juga telah berupaya untuk meningkatkan kemampuan pemecahan masalah matematis siswa. Salah satu cara guru untuk meningkatkan kemampuan belajar siswa dengan menggunakan metode-metode belajar seperti tutor sebaya, namun tetap saja belum dapat memfasilitasi kemampuan pemecahan masalah matematis siswa.

Berdasarkan masalah tersebut, peneliti tertarik untuk melakukan penelitian pengembangan, yaitu pengembangan bahan ajar berupa Lembar Kerja Siswa berbasis Problem Solving. LKS berbasis Problem Solving merupakan suatu bahan ajar yang melatih siswa dalam menyelesaikan permasalahan matematika. LKS tersebut berupa lembaran-lembaran berisi masalah yang harus diselesaikan oleh siswa dengan menggunakan langkah-langkah pemecahan masalah (Rosmawati, 2012: 80). Menurut Polya solusi pemecahan masalah memuat empat langkah penyelesaian yaitu memahami masalah, merencanakan penyelesaian, menyelesaikan masalah dan melakukan pemeriksaan kembali terhadap semua langkah yang dikerjakan. Keempat langkah tersebut merupakan suatu kesinambungan dan kesatuan yang tidak dapat dipisahkan, untuk menyelesaikan suatu permasalahan, siswa harus mampu memahami permasalahan tersebut dengan tepat. Tanpa adanya pemahaman yang benar, mereka tidak mungkin bisa menyusun rencana penyelesaian. Penyusunan rencana penyelesaian juga dipengaruhi oleh pengalaman siswa dalam menyelesaiakan suatu permasalahan. Jika rencana penyelesaian telah disusun, barulah permasalahan tersebut dapat diselesaikan sesuai rencana. Selanjutnya diperlukan peninjauan/pemeriksaan kembali proses penyelesaian yang telah dilakukan untuk memastikan kebenaran dalam penyelesaian. Jadi, dengan memberikan LKS berbasis Problem Solving kepada siswa maka siswa akan mendapatkan banyak kesempatan untuk latihan 
memecahkan masalah. Dengan terbiasanya siswa memecahkan masalah yang ada pada LKS berbasis problem solving, maka siswa dapat memiliki kemampuan pemecahan masalah matematis yang baik.

\section{METODE}

Bagian Jenis penelitian yang dilakukan adalah penelitian dan pengembangan (Research and Development). Research and Development adalah suatu proses atau langkah-langkah untuk mengembangkan suatu produk baru atau menyempurnakan produk yang telah ada, yang dapat dipertanggungjawabkan (Nana, 2013: 164). Subjek uji coba dalam menentukan praktikalitas LKS adalah siswa kelas VII MTsN Terantang Kecamatan Tambang Kabupaten Kampar. Objek penelitian ini adalah Pengembangan LKS Berbasis Problem Solving.

Rancangan penelitian pengembangan ini menggunakan model pengembangan ADDIE. Model ADDIE terdiri dari lima fase atau tahap utama yaitu Analysis, Design, Development, Implementation, dan Evaluation. Kelima fase atau tahap dalam model ADDIE, perlu dilakukan secara sistemik dan sistematik (Benny, 2009: 125).

Adapun fase atau tahap prosedur penelitian dengan menggunakan model ADDIE sebagai berikut:

\section{Analysis (Tahap Analisis)}

Langkah analisis terdiri dari dua tahap, yaitu analisis kinerja atau performance analysis dan analisis kebutuhan atau need analysis (Benny, 2009: 128). Tahapan ini dijelaskan secara rinci yaitu: Pertama, Analisis Kinerja Analisis kinerja dilakukan untuk mengetahui dan mengklarifikasi apakah masalah kinerja yang dihadapai memerlukan solusi berupa penyelenggaraan program atau perbaikan manajemen. Analisis kinerja dalam penelitian ini bertujuan untuk mengetahui dan mengklarifikasi masalah yang dihadapi dalam pembelajaran. Permasalahan yang dihadapai dalam penelitaian ini adalah masih terbatasnya LKS yang dibuat guru sendiri sebagai bahan ajar dasar-dasar matematika dalam proses pembelajaran di sekolah. Sehingga dibutuhkan solusi berupa perbaikan kualitas manajemen dalam proses pembelajaran. Solusi dari permasalahan tersebut bisa dilakukan dengan cara penyediaan fasilitas pembelajaran yang memadai, misalnnya tersedia LKS yang disusun guru mata pelajaran matematika sebagai bahan ajar matematika yang mengutamakan aktivitas belajar siswa. Kedua, Analisis Kebutuhan Analisis kebutuhan merupakan langkah yang diperlukan untuk menentukan kemampuan-kemampuan atau kompetensi yang perlu dipelajarai oleh siswa untuk meningkatkan kinerja atau prestasi belajar.

\section{Design (Tahap Perancangan)}

Pada tahap perancangan (design) pengembangan LKS berbasis Problem solving dilakukan langkahlangkah sebagai berikut: Pertama, menetapkan judul LKS. Judul LKS ditentukan berdasarkan kompetensi dasar, indikator-indikator, dan materi pembelajaran yang tercantum dalam kurikulum. Kedua, menyiapkan buku-buku sumber dan buku referensi lainnya. Pengumpulan materi pokok dilakukan dengan menggunakan sumber-sumber atau buku-buku mata pelajaran yang sudah ada, memanfaatkan buku dan internet dan referensi lainnya. Ketiga, melakukan identifikasi terhadap kompetensi dasar, serta merancang bentuk kegiatan pembelajaran yang sesuai. Keempat, mengidentifikasi indikator pencapaian kompetensi dan merancang bentuk dan jenis penilaian yangakan disajikan. Terakhir yang kelima yaitu merancang LKS.

\section{Development (Tahap Pengembangan)}

Pada langkah pengembangan (development) ini, dikembangan LKS matematika berbasis Problem Solving dengan tahapan pengembangan LKS berdasarkan hal-hal berikut: Berbentuk media cetak, untuk mempermudah bagi pemakainya. Dirancang secara menarik, bervariasi, dan komunikatif. Dilengkapi dengan informasi berupa teks dan gambar. Disusun berdasarkan format penulisan 
Lembar Kerja Siswa (LKS). Lembar Kerja Siswa (LKS) yang telah dikembangkan kemudian diujikan kepada ahli teknologi pendidikan dan ahli materi pembelajaran matematika supaya mendapat masukan untuk pengembangan dan perbaikan sebelum diujicobakan.

4. Implementation (Tahap Implementasi)

Tahap Implementasi dilakukan untuk mendapatkan data kelayakan sebagai produk yang dikembangkan. Produk yang telah dinyatakan valid oleh validator ahli materi dan validator ahli teknologi kemudian diuji cobakan kepada siswa. Uji coba yang dilakukan adalah uji coba kelompok kecil dan uji coba lapangan terbatas. Uji coba kelompok kecil terdiri dari 6 orang siswa. Sedangkan uji coba lapangan terbatas dilakukan pada siswa satu kelas yang terdiri dari 25 orang siswa. Setelah menggunakan produk yang dikembangkan, siswa diminta untuk mengisi angket uji praktikalitas. Adapun tujuannya agar siswa sebagai pengguna LKS secara langsung dapat menilai dan memaparkan kekurangan pada LKS yang digunakan. Informasi tersebut dapat menjadi bahan pertimbangan dalam proses revisi sehingga akan diperoleh produk yang dapat memenuhi kebutuhan siswa.

5. Evaluation (Tahap Evaluasi)

Evaluasi adalah sebuah proses pengumpulan data untuk menentukan sejauh mana, dalam hal apa, dan bagian mana tujuan pendidikan yang sudah tercapai. Jika belum, bagian mana yang belum dan apa sebabnya. Evaluasi juga merupakan sebuah tahap untuk merevisi kembali hasil yang telah didapatkan. Pada langkah evaluasi ini bertujuan untuk menganalisis kevalidan dan kepraktisan LKS yang dikembangkan.

Teknik Pengumpulan Data terdiri dari tiga jenis yaitu pertama, angket yang diberikan kepada siswa untuk mengetahui respon mereka setelah menggunakan LKS. Kedua, lembar validasi yaitu lembaran-lembaran penilaian yang digunakan untuk menilai instrumen dan produk yang dikembangkan. Lembar validasi disusun berdasarkan format angket. Lembar validasi ini ditujukan kepada ahli materi pembelajaran dan ahli teknologi pendidikan. Ketiga yaitu tes, yang diberikan berisi serangkaian pertanyaan atau latihan untuk dijawab oleh siswa. Tes digunakan untuk mengumpulkan data mengenai kemampuan pemecahan masalah.

Teknik analisis data yang digunakan pada penelitian ini adalah teknik analisis deskriptif kualitatif dan teknik analisis deskriptif kuantitatif. Analisis deskriptif kualitatif ini digunakan untuk mengelola data hasil review ahli materi pembelajaran dan ahli teknologi pendidikan berupa saran dan komentar mengenai perbaikan LKS berbasis problem solving. Analisis deskriptif kuantitatif yang mendeskripsikan hasil uji validitas dan praktikalitas LKS berbasis Problem Solving. Analisis deskriptif kuantitatif dengan cara menganalisis data kuantitatif berupa angka yang diperoleh dari angket dan tes.

\section{HASIL DAN PEMBAHASAN}

\section{Hasil}

Produk yang dihasilkan dalam penelitian dan pengembangan ini berupa Lembar Kerja Siswa berbasis problem solving dengan materi pokok bangun datar segiempat untuk siswa kelas VII $\mathrm{SMP} /$ Sederajat. Lembar Kerja Siswa berbasis problem solving disusun sesuai dengan langkah model pengembangan ADDIE yaitu Analysis, Design, Development, Implementation, dan Evaluation. Adapun tahap-tahap pengembangannya diuraikan sebagai berikut:

Analysis (Tahap Analisis).

Pertama, Analisis Kinerja Analisis kinerja dilakukan dengan merincikan isi materi materi ajar dalam bentuk garis besar. Analisis ini mencakup: Analisis Struktur Isi yaitu berdasarkan kurikulum KTSP mata pelajaran matematika kelas VII SMP/Sederajat. Analisis Konsep yaitu Lembar Kerja Siswa ini berisi beberapa materi yang berkaitan dengan segi empat, sebagai berikut: 
Bentuk-bentuk segi empat, jenis-jenis segi empat, sifat-sifat segi empat, dan keliling dan luas segi empat. Kedua, Analisis Kebutuhan Lembar Kerja Siswa akan digunakan untuk siswa kelas VII SMP yang berusia lebih kurang 11-13 tahun. Pada usia 11 atau 12 tahun keatas seorang remaja sudah dapat berfikir logis, logika remaja mulai berkembang dan digunakan. Keadaan siswa yang cenderung pasif dan menunjukan perhatian yang kurang terhadap pembelajaran yang sedang berlangsung dan dinilai kurang menyenangkan. Pembelajaran yang diciptakan dalam suatu pembelajaran harus mampu menarik perhatian dari siswa, karena menurut beberapa penelitian membuktikan bahwa perhatian anak didik berkurang bersamaan dengan berlalunya waktu. Penelitian Pollio menunjukan bahwa siswa dalam ruang kelas hanya memperhatikan pelajaran sekitar 40\% dari waktu pembelajaran yang tersedia. Penelitian Mc Keachie menyebutkan bahwa dalam sepuluh menit pertama perhatian siswa dapat mencapai $70 \%$ dan berkurang sampai menjadi $20 \%$ pada waktu 20 menit terakhir.

\section{Design (Tahap Perancangan)}

Design (Tahap perancangan) merupakan tahapan untuk merancang LKS berbasis problem solving serta komponen-komponen yang berkaitan dengan LKS tersebut. Berikut ditampilkan beberapa komponen LKS berbasis problem solving. Pertama, Cover dan Peta Konsep Cover atau sampul merupakan salah satu unsur penting terhadap daya tarik siswa untuk membaca. Peta konsep adalah unsur yang sangat penting dalam sebuah bahan ajar karena peta menjadikan pembelajaran lebih terarah. Tampilan cover dan peta konsep pada LKS berbasis problem solving seperti tampilan pada gambar berikut.
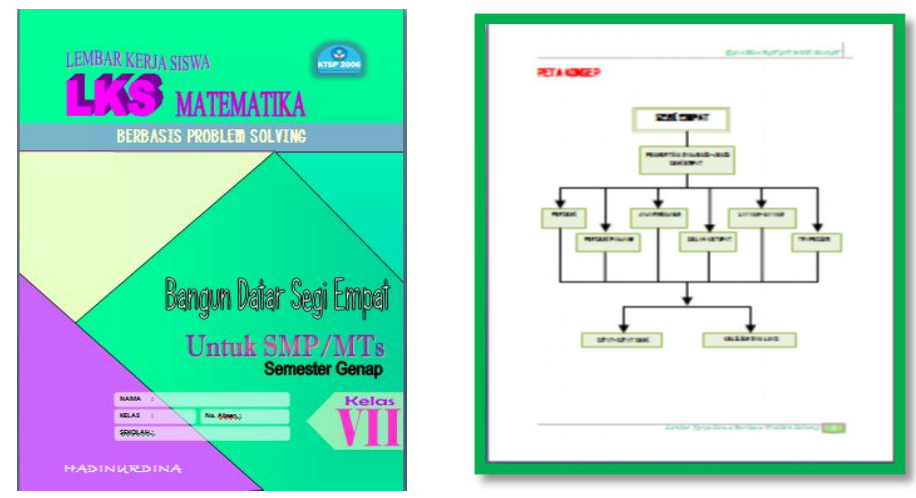

Gambar 1. Cover dan Peta Konsep LKS

Selanjutnya kegiatan belajar yang terdiri dari penyajian materi pada kegiatan belajar, dengan gambar sebagai berikut.
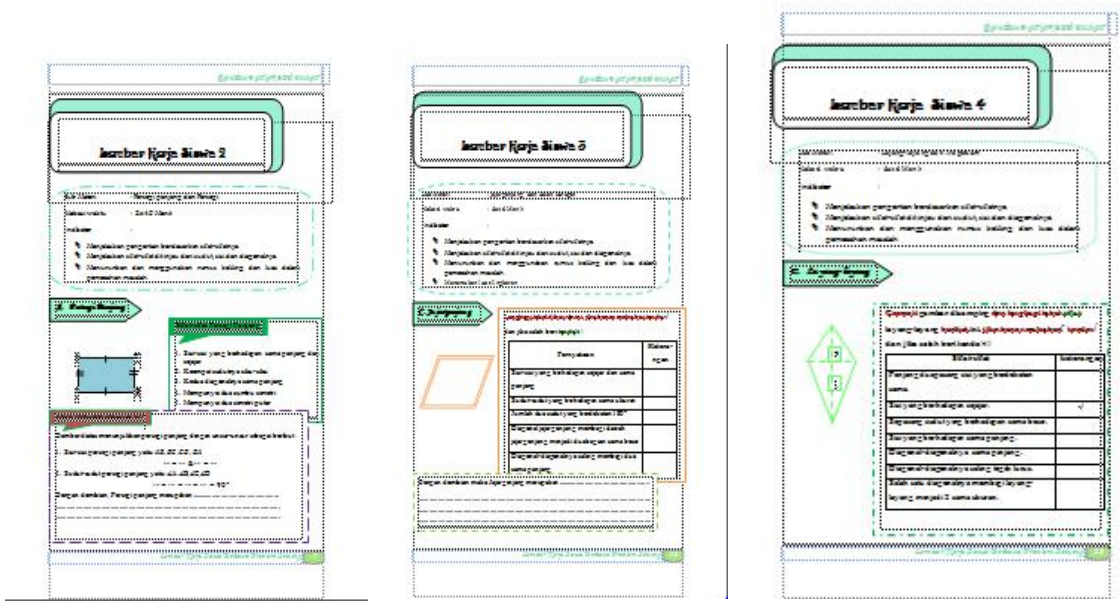
Desain animasi yang digunakan dapat membuat siswa lebih tertarik seperti pada gambar berikut:

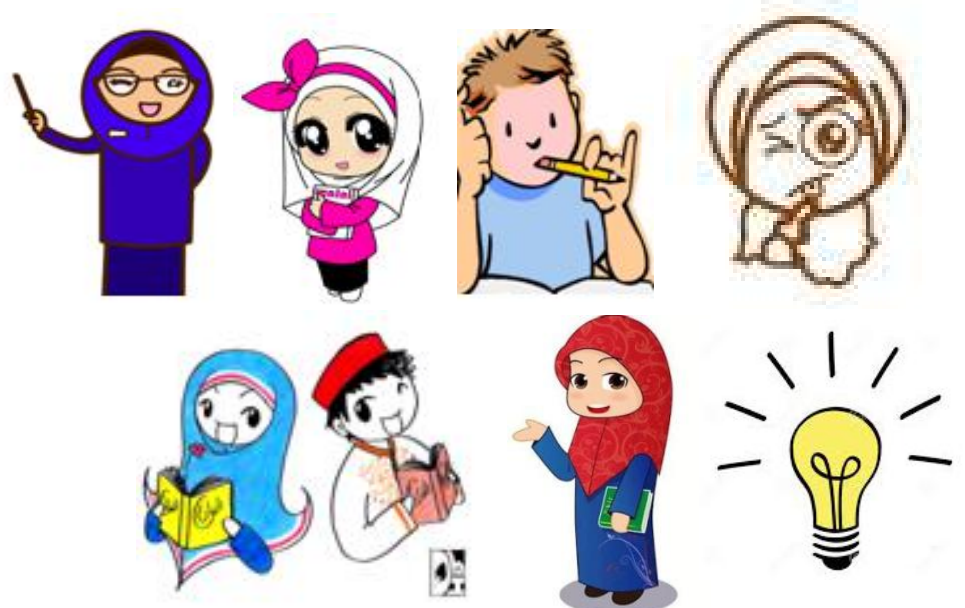

Gambar 4. Animasi dalam LKS

\section{Development (Tabap pengembangan)}

Setelah pembuatan desain LKS oleh peneliti selesai, LKS yang dirancang kemudian di validasi oleh validator ahli teknologi pendidikan dan ahli materi pembelajaran dengan menggunakan lembar uji validitas. Validasi ini bertujuan untuk melihat apakah LKS yang dibuat sudah layak atau tidak untuk di uji cobakan. Validasi LKS berbasis problem solving dilakukan dengan cara menghadirkan ahli teknologi pendidikan dan ahli materi pembelajaran. Hal ini dilakukan agar LKS yang dikembangkan dapat di nilai serta diberi saran perbaikan untuk direvisi sehingga diperoleh LKS yang baik. Berikut ini disajikan hasil penilaian dan tanggapan dari ahli teknologi pendidikan dan ahli materi pembelajaran dari instansi UIN Suska dan MTsN Terantang. Rata-rata persentase tingkat validitas dari kedua ahli materi pembelajaran adalah sebesar 82,63\% dengan kategori sangat valid. Validasi teknologi pendidikan yang juga divalidasi oleh dua orang validator. Validator ahli teknologi pendidikan menilai bagian desain LKS yang dikembangkan, dari segi gambar, warna, penggunaan tulisan dan sebagainya. Hasil validasi dari kedua ahli teknologi terhadap LKS berbasis Problem solving dinyatakan sangat valid dengan tingkat validitas adalah 85\%.

\section{Implementation (Tabap uji coba produk)}

Semua data dari hasil review, Penilaian dan diskusi dari para ahli teknologi pendidikan dan ahli materi pembelajaran dijadikan bahan pertimbangan dalam rangka revisi LKS berbasis problem solving sebelum dilakukan uji coba lapangan. Berdasarkan saran dari para ahli terdapat beberapa komponen yang perlu diperbaiki. Hal ini bertujuan agar LKS berbasis problem solving yang dikembangkan semakin baik. Setelah direvisi berdasarkan ahli teknologi pendidikan dan ahli materi pembelajaran. Selanjutnya LKS diuji cobakan pada kelompok kecil dan siswa satu kelas melalui angket praktikalitas LKS. Uji coba kelompok kecil dilakukan dikelas VII MTsN Terantang dengan siswa yang berjumlah 6 orang siswa. Keenam siswa ini diberikan masingmasing LKS dan diberi waktu dua hari untuk mempelajari LKS tersebut dirumah. Kemudian pada hari ketiga siswa dikumpulkan untuk melakukan diskusi dan diminta mengisi angket praktikalitas. Hal ini dilakukan untuk mengetahui kepraktisan dari penggunaan LKS dan mendapat masukan yang dapat dipertimbangkan dalam perbaikan LKS sebelum diujicobakan ke kelompok yang lebih besar. Persentase keseluruhan dari penilaian siswa dalam uji praktikalitas adalah sangat praktis, karena rata-rata persentase keseluruhan nilai kepraktisan yaitu 82,90\%. Uji lapangan terbatas (kelompok besar) dilakukan pada kelas VII ${ }^{\mathbf{B}}$ MTsN Terantang yang berjumlah 
25 orang siswa. Uji coba kelompok besar dilakukan 4 kali pertemuan. Pada pertemuan kelima siswa diberikan angket untuk menilai praktikalitas LKS. Persentase keseluruhan dari penilaian siswa dalam uji praktikalitas adalah sangat praktis, karena rata-rata persentase keseluruhan nilai kepraktisan yaitu $85,22 \%$. Persentase keseluruhan dari uji coba kelompok kecil dan lapangan terbatas adalah $84,06 \%$ dengan kategori sangat praktis karena berada pada rentang $81 \%-100 \%$.

Setelah materi pada LKS selesai, pada pertemuan kelima selain angket siswa juga diberikan soal posttest. Posttest dimaksudkan untuk mengetahui tingkat kemampuan pemecahan masalah matematis siswa terhadap materi segi empat setelah pembelajaran menggunakan LKS problem solving. Nilai posttest kemampuan pemecahan masalah matematis 21 siswa dari 25 siswa telah tuntas dalam pembelajaran dengan nilai diatas KKM (75). Nilai rata-rata kelas juga menunjukkan diatas KKM yaitu 82 dengan persentase kelulusan $84 \%$ dan tingkat kemampuan pemecahan masalah matematisnya adalah $80,20 \%$, maka LKS berbasis problem solving dikatakan dapat memfasilitasi kemampuan pemecahan masalah matematis siswa.

\section{Tahap Evaluasi (Evaluation)}

Tahap evaluasi dilakukan setelah melakukan validasi dan uji coba lapangan. LKS berbasis problem solving sudah dinyatakan valid oleh ahli teknologi pendidikan dan ahli materi pembelajaran. Kemudian, pada tahap uji coba diperoleh hasil sangat praktis dan dapat memfasilitasi kemampuan pemecahan masalah matematis siswa. Namun saran-saran yang diberikan validator dijadikan sebagai bahan pertimbangan dan penyempurnaan LKS berbasis problem solving. Peneliti telah melaksanakan evaluasi terhadap LKS berbasis problem solving sesuai saran dari tim ahli dan siswa. Setelah LKS direvisi dan sebelum LKS diuji cobakan, peneliti melakukan uji coba pemakaian produk pada lapangan kecil dengan jumlah responden 6 siswa. Hal ini dilakukan untuk menguji apakah di dalam LKS masih ditemukan kesalahan dan kekurangan dan meminta saran perbaikan dari siswa berdasarkan kesalahan dan kekurangan yang ditemukan oleh siswa, yang kemudian saran tersebut akan dijadikan bahan perbaikan setelah uji coba lapangan kecil tersebut. Ternyata ketika uji coba lapangan kecil yang dilakukan, siswa menemukan kekurangan dan ada beberapa siswa yang memberikan saran. Saran-saran siswa dijadikan bahan pertimbangan dalam mengevaluasi serta merevisi LKS yang dikembangkan. Peneliti telah melakukan revisi sesuai saran-saran dari validator dan siswa

\section{Diskusi}

\section{Analisis Validasi LKS.}

Validasi Ahli materi pembelajaran terdiri dari syarat didaktif, syarat Kontruksi dan problem solving. Berdasarkan syarat didaktik hasil validasi LKS Problem Solving adalah $82 \%$ yang dikategorikan sangat valid. Berikut rincian dari syarat didaktik: Indikator A yaitu materi mencakup pada kurikulum yang berlaku dalam menunjang pencapaian kompetensi serta sesuai dengan indikator pembelajaran hasil validasinya $87,50 \%$ yang dikategorikan sangat valid. Indikator B yaitu memberikan penekanan pada proses untuk memecakan masalah hasil validasinya $76,67 \%$ yang dikategorikan valid. Indikator C yaitu latihan soal dalam LKS dapat mengukur ketercapaian kompetensi hasil validasinya 80\% yang dikategorikan valid. Berdasarkan Syarat Konstruksi hasil validasi LKS Problem Solving adalah 85\% yang dikategorikan sangat valid. Berikut rincian dari syarat konstruksi: Indikator A yaitu menggunakan bahasa sesuai dengan tingkat perkembangan siswa hasil validasinya $80 \%$ yang dikategorikan valid. Indikator B yaitu materi yang disajikan memiliki judul materi, membuat rincian materi pokok serta disajikan dengan sederhana dan jelas hasil validasinya $90 \%$ yang dikategorikan sangat valid. Indikator C yaitu menyediakan ruang yang cukup pada LKS sehingga siswa dapat menulis dan menggambarkan sesuatu pada LKS hasil validasinya $80 \%$ yang dikategorikan valid. Indikator D yaitu kelengkapan LKS hasil validasinya $90 \%$ yang dikategorikan sangat valid. Indikator E yaitu memiliki tujuan belajar yang jelas serta bermanfaat hasil validasinya $80 \%$ yang dikategorikan valid. Adapun penilaian Pendekatan Problem 
Solving pada LKS adalah 82,50\% yang dikategorikan sangat valid, dengan rincian sebagai berikut: Tahap mengorientasikan masalah hasil validasinya $90 \%$ yang dikategorikan sangat valid. Tahap merencanakan penyelesaian masalah hasil validasinya $80 \%$ yang dikategorikan valid. Tahap memecahkan masalah hasil validasinya $80 \%$ yang dikategorikan valid. Tahap mengevaluasi hasil, hasil validasinya $80 \%$ yang dikategorikan valid. Validasi ahli teknologi pendidikan, berdasarkan syarat teknis hasil validasi LKS berbasis Poblem Solving adalah 85,29\% yang dikategorikan valid. Berikut rincian dari syarat teknis: Indikator A yaitu penggunaan huruf dan tulisan hasil validasinya $85,71 \%$ yang dikategorikan sangat valid. Indikator B yaitu desain LKS hasil validasinya 84,29\% yang dikategorikan sangat valid. Indikator $C$ yaitu penggunaan gambar hasil validasinya $90 \%$ yang dikategorikan sangat valid. Indikator D yaitu Tampilan LKS hasil validasinya $80 \%$ yang dikategorikan valid.

\section{Analisis Praktikalitas LKS}

Pada praktikalitas Kelompok Kecil, berdasarkan penilaian minat dan tampilan LKS bahwa hasil praktikalitas LKS adalah $83 \%$ yang dikategorikan sangat praktis. Berikut rincian minat siswa dan tampilan LKS: Indikator A yaitu tampilan LKS menarik minat siswa dalam menggunakannya hasil praktikalitasnya $83,89 \%$ yang dikategorikan sangat praktis. Indikator B yaitu ketertarikan siswa terhadap pembelajaran matematika dengan menggunakan LKS yang dikembangkan hasil praktikalitasnya $81,67 \%$ yang dikategorikan sangat praktis. Berdasarkan proses penggunaan hasil praktikalitas LKS adalah $82 \%$ yang dikategorikan sangat praktis. Berikut rincian proses penggunaan: indikator A yaitu LKS bersifat lebih praktis dan penggunaannya dapat disesuaikan dengan kecepatan belajar siswa hasil praktikalitasnya 82,50\% yang dikategorikan sangat praktis. Indikator B yaitu penggunaan LKS meningkatkan aktivitas belajar siswa hasil praktikalitasnya $80 \%$ yang dikategorikan praktis. Berdasarkan pendekatan problem solving dan pemecahan masalah hasil praktikalitas LKS $83,89 \%$ yang dikategorikan sangat praktis, dengan rincian: Indikator A yaitu LKS dapat membuat siswa menghubungkan materi yang dipelajari dengan konteks nyata dalam kehidupan sehari-hari hasil praktikalitasnya 80\% yang dikategorikan sangat praktis. Indikator B yaitu LKS dapat meningkatkan pemecahan masalah, daya ingat dan merangsang daya pikir siswa hasil praktikalitasnya $83,33 \%$ yang dikategorikan sangat praktis. Indikator C yaitu LKS dapat membantu siswa dalam pemecahan masalah, hasil praktikalitasnya 86,67\% yang dikategorikan sangat praktis. Berdasarkan indikator penggunaan LKS dapat menghemat waktu hasil praktikalitasnya $80 \%$ yang dikategorikan praktis. Berdasarkan indikator latihan soal di LKS dapat membantu meningkatkan pemecahan masalah matematis siswa hasil praktikalitasnya 82,90\% yang dikategorikan sangat praktis. Pada Praktikalitas Kelompok Besar., berdasarkan penilaian minat dan tampilan LKS bahwa hasil praktikalitas LKS adalah 85,84\% yang dikategorikan sangat praktis. Berikut rincian minat siswa dan tampilan LKS: Indikator A yaitu tampilan LKS menarik minat siswa dalam menggunakannya hasil praktikalitasnya 86,\% yang dikategorikan sangat praktis. Indikator B yaitu ketertarikan siswa terhadap pembelajaran matematika dengan menggunakan LKS yang dikembangkan hasil praktikalitasnya $85,60 \%$ yang dikategorikan sangat praktis. Berdasarkan proses penggunaan hasil praktikalitas LKS adalah $85,28 \%$ yang dikategorikan sangat praktis. Berikut rincian proses penggunaan: Indikator A yaitu LKS bersifat lebih praktis dan penggunaannya dapat disesuaikan dengan kecepatan belajar siswa hasil praktikalitasnya $85,40 \%$ yang dikategorikan sangat praktis. Indikator B yaitu penggunaan LKS meningkatkan aktivitas belajar siswa hasil praktikalitasnya $84,80 \%$ yang dikategorikan sangat praktis. Berdasarkan pendekatan problem solving dan pemecahan masalah hasil praktikalitas LKS adalah $84 \%$ yang dikategorikan sangat praktis, dengan rinciannya: Indikator A yaitu LKS dapat membuat siswa menghubungkan materi yang dipelajari dengan konteks nyata dalam kehidupan sehari-hari hasil praktikalitasnya $82,40 \%$ yang dikategorikan sangat praktis. Indikator B yaitu LKS dapat meningkatkan pemecahan masalah, daya ingat dan merangsang daya pikir siswa hasil praktikalitasnya $83,20 \%$ yang dikategorikan sangat praktis. Indikator C yaitu LKS dapat membantu siswa dalam pemecahan masalah hasil praktikalitasnya 85,33\% yang dikategorikan 
sangat praktis. Berdasarkan indikator penggunaan LKS dapat menghemat waktu hasil praktikalitasnya $82,40 \%$ yang dikategorikan sangat praktis. Berdasarkan indikator latihan soal di LKS dapat membantu meningkatkan pemecahan masalah matematis siswa hasil praktikalitasnya $88,80 \%$ yang dikategorikan sangat praktis.

\section{Analisis Kemampuan Pemecahan Masalah}

Setelah siswa diberikan pembelajaran dengan menggunakan LKS berbasis problem solving, maka diakhir pembelajaran siswa diberikan posttest guna mengetahui tingkat kemampuan pemcahan masalah matematis siswa. Dari hasil analisis data posttest diperoleh tingkat kemampuan pemecahan masalah matematis siswa adalah 80,20\% dengan kriteria tinggi. Hal ini menunjukkan bahwa LKS yang dikembangkan telah dapat memfasilitasi kemampuan pemecahan masalah matematis siswa. Dari hasil analisis posttest juga terlihat bahwa terdapat 4 siswa yang termasuk ke dalam kategori tidak tuntas disebabkan nilai yang diperolehnya di bawah KKM $(<75)$ dan 21 orang siswa lainnya termasuk dalam kategori tuntas karena nilainya $\geq 75$. Tingkat ketuntasan siswa mencapai $84 \%$ dengan nilai rata-rata kelas adalah 82. Secara rinci akan dijelaskan tingkat kemampuan pemecahan masalah matematis siswa. Berdasarkan analisis hasil posttest siswa dapat dijelaskan sebagai berikut. Berdasarkan indikator mengidentifikasi unsur-unsur yang diketahui dan yang ditanyakan dan kecukupan unsur lainnya, didapatkan bahwa hasil posttest siswa termasuk predikat tinggi dengan presentase keidealan 90,67\%. Dengan demikian siswa telah mampu mengidentifikasi dengan benar unsur-unsur yang diketahui dan yang ditanyakan dan kecukupan unsur lainnya menggunakan LKS berbasis problem solving. Berdasarkan indikator merencanakan penyelesaian masalah didapatkan bahwa hasil posttest siswa termasuk predikat sedang dengan presentase keidealan 70,40\%. Demikian siswa telah mampu menerapkan strategi untuk menyelesaikan masalah dengan benar menggunakanLKS berbasis problem solving. Berdasarkan indikator melaksanakan penyelesaian masalah didapatkan bahwa hasil posttest siswa termasuk predikat tinggi dengan presentase keidealan $87,73 \%$. Demikian siswa telah mampu menerapkan strategi untuk menyelesaikan masalah dengan benar menggunakan LKS berbasis problem solving. Berdasarkan indikator menjelaskan dan menginterpretasikan hasil, didapatkan bahwa hasil posttest siswa termasuk predikat sedang dengan presentase keidealan 72,00\%. Dengan demikian siswa telah mampu menjelaskan dan menginterpretasikan hasil dengan benar menggunakan LKS berbasis problem solving .

\section{REFERENSI}

Abdul Majid. (2008). Perencanaan Mengembangkan Standar Kompeteni Guru. Bandung: PT. Remaja Rosdakarya.

Agus Suprijono. (2013). Cooperative Learning. Yogyakarta: Pustaka Pelajar.

Ahmad Susanto. (2013). Teori Belajar dan Pembelajaran di Sekolah Dasar. Jakarta: Kencana.

Andi Prastowo. (2013). Panduan Kreatif Membuat Bahan Ajar Inovatif. Jogjakarta: DIVA Press.

Benny A. Pribadi. (2009). .Model Desain Sistem Pembelajaran. Jakarta: Dian Rakyat.

Effandi Zakaria. (2007). Trend Pengajaran dan Pembelajaran Matematika. Kuala Lumpur: Loh Prin SDN, BHD.

E. Mulyasa. (2009). Kurikulum yang Disempurnakan Pengembangan Standar Kompetensi Dasar. Bandung: PT. Remaja Rosdakarya.

Fadjar Sadiq. (2004). Pemecahan Masalah, Penalaran, dan Komunikasi Matematika. Departemen Pendidikan Nasional: Yogyakarta.

Jarnawi D Afgani. (2011). Materi Pokok Analisis Kurikulum Matematika. Jakarta: Universitas Terbuka. 
Nana Syaodih Sukmadinata. (2013). .Metode Penelitian Pendidikan. Bandung: PT. Remaja Rosdakarya.

Rosmawati dkk, Kemampuan Pemecaban Masalab dan Lembar Kegiatan Siswa Berbasis Problem Solving,

(FMIPA UNP, 2012) Vol. No. 1 Jurnal Pendidikan Matematika, Part 3 : hal 80

Syaiful Bahri Djamarah. (2010). Strategi Belajar Mengajar. Jakarta: Rineka Cipta. 